\title{
Influence of Temperature and Time Carbonization on Calorific Value of Charcoal Briquette Raw Materials Areca Nut Husk
}

\section{Pengaruh Temperatur dan Waktu Karbonisasi terhadap Nilai Kalor Briket Arang Berbahan Baku Serat Buah Pinang}

\author{
Riski Camarta ${ }^{1 *}$, Hendri Nurdin ${ }^{1}$, Nelvi Erizon ${ }^{1}$, Andril Arafat $^{1}$
}

\begin{abstract}
Areca nut husk is one type of biomass that can be used as raw material for briquettes as an alternative energy producer in reducing the use of fossil fuels (petroleum). Charcoal briquettes are solid fuels that can be used as alternative fuels in an effort to meet energy needs. Briquette making using tapioca adhesive with biomass and adhesive composition used in this study was $80 \%$ and $20 \%$. Comparison of this composition is known to produce a relatively high heating value of briquettes. The quality of charcoal briquettes can be determined from the high temperature and carbonization time. This study aims to assess the quality of areca nut charcoal briquettes through carbonization at temperatures of $200{ }^{\circ} \mathrm{C}, 250$ ${ }^{\circ} \mathrm{C}, 300^{\circ} \mathrm{C}, 350^{\circ} \mathrm{C}$ and $400^{\circ} \mathrm{C}$ at holding times for 30, 60 and 90 minutes. The study was conducted by pyrolysis of areca nut briquettes which had been formed and dried. Testing the quality of charcoal briquettes includes calorific value analysis. The results of this study indicate the highest heating value of coir briquette charcoal is at carbonization temperature of $300^{\circ} \mathrm{C}$ for 60 minutes at 20979,13632 $\mathrm{KJ} / \mathrm{Kg}$.
\end{abstract}

\section{Keywords}

Areca Nut husk, Carbonization Temperature, Calorific Value, Tapioca Adhesive, Charcoal Briquette

\begin{abstract}
Abstrak
Serat buah pinang merupakan salah satu jenis biomassa yang dapat dimanfaatkan menjadi bahan baku briket sebagai penghasil energi alternatif dalam mengurangi penggunaan bahan bakar fosil (minyak bumi). Briket arang merupakan bahan bakar padat yang dapat dijadikan sebagai bahan bakar alternatif dalam upaya untuk dapat memenuhi kebutuhan energi. Pembuatan briket menggunakan perekat tapioka dengan komposisi biomassa dan perekat sebanyak $80 \%$ dan $20 \%$. Penelitian ini bertujuan untuk mengkaji kualitas briket arang serat buah pinang melalui proses karbonisasi pada temperatur $200^{\circ} \mathrm{C}, 250^{\circ} \mathrm{C}, 300^{\circ} \mathrm{C}, 350^{\circ} \mathrm{C}$ dan $400^{\circ} \mathrm{C}$ pada waktu tahan selama 30,60 dan 90 menit. Pengujian kualitas briket arang meliputi analisis nilai kalor. Hasil penelitian ini menunjukkan nilai kalor briket arang serat buah pinang tertinggi terdapat pada temperatur karbonisasi $300^{\circ} \mathrm{C}$ selama 60 menit sebesar 20979,13632 KJ/Kg.
\end{abstract}

\section{Kata Kunci}

Serat Buah Pinang, Temperatur Karbonisasi, Nilai Kalor, Perekat Tapioka, Briket Arang

${ }^{1}$ Pendidikan Teknik Mesin, Universitas Negeri Padang

Fakultas Teknik, Kampus UNP Air Tawar, Jl. Prof. Dr. Hamka, Padang, Sumatera Barat. Kode Pos 25132

* rizkimarta11@gmail.com

Submitted : February 04, 2020. Accepted : February 18, 2020. Published : May 01, 2020. 


\section{PENDAHULUAN}

Kebutuhan energi pada era sekarang ini semakin meningkat seiring bertambahnya populasi manusia dan perekonomian masyarakat dunia. Cadangan energi minyak bumi yang semakin menipis telah menjadi masalah utama dalam mencari sumber energi alternatif dalam mengurangi penggunaan energi fosil sebagai bahan bakar minyak. Kelangkaan sumber energi yang sangat ekstrim telah dirasakan dari ketidakseimbangan permintaan dan penyediaan sumber energi utama yang selama ini hanya berasal dari energi fosil selalu mengalami penurunan setiap tahun. Hal ini harus diimbangi dengan penyediaan sumber energi yang renewable, jumlahnya melimpah dengan biaya produksi lebih murah. Sumber energi pengganti ini harus didasarkan pada bahan bakunya yang mudah diperoleh dan dapat diperbaharui serta produknya mudah digunakan [12]. Serat buah pinang merupakan ampas hasil pengolahan biji pinang. Total hasil panen pinang perkebunan rakyat di provinsi sumatera barat pada tahun 2017 tercatat sebesar 7.683,16 ton. Besarnya sumber daya alam ini memungkinkan untuk diolah menjadi penghasil energi dalam mengurangi penggunaan energi fosil. Pemanfaatan serat buah pinang pada umumnya hanya terbatas sebagai produk sisa hasil pengolahan biji pinang yang seringkali dibuang begitu saja. Serat ini dapat dimanfaatkan sebagai sumber energi terbarukan, salah satunya adalah sebagai bahan bakar briket arang.

Proses pembuatan briket arang memerlukan perekatan yang bertujuan untuk mengikat partikel-partikel arang sehingga menjadi padat dengan kerapatan tinggi. Perekat yang umumnya digunakan dalam pembuatan briket adalah pati tapioka (kanji) karena memiliki kemampuan merekat yang baik dengan kadar tanin 18,7\% [4]. Pati (kanji) ini dapat diperoleh dari tumbuh-tumbuhan seperti tanaman jagung, kentang, ubi kayu dan tanaman lainya (Sulistyanto, 2007). Perekat yang digunakan dalam penelitian briket arang ini adalah pati tepung tapioka, karena bahan tersebut mudah didapatkan dan mempunyai harga yang relatif lebih murah. Serat buah pinang memiliki prospek yang baik dijadikan sebagai bahan bakar briket arang yang dapat memenuhi kebutuhan energi. Salah satu yang membedakan bahan serat buah pinang dengan beberapa biomassa lainya adalah memiliki kandungan selulosa dan lignin cukup tinggi. Komposisi sabut pinang dapat dilihat pada tabel 1 [10].

\section{Tabel 1. Komposisi sabut Pinang}

\begin{tabular}{lll}
\hline & Komposisi & Persentase \\
\hline 1 & Selulosa & 53,20 \\
2 & Hemiselulosa & 32,98 \\
3 & Lignin & 7,20 \\
4 & Fat and Wax & 0,64 \\
5 & Ash & 1,05 \\
6 & Lain-lain & 3,12 \\
\hline
\end{tabular}

Komposisi serat buah pinang pada tabel 1 menunjukkan serat buah pinang berpotensi dijadikan bahan bakar briket arang. Briket arang merupakan salah satu jenis bahan bakar padat yang dihasilkan melalui proses karbonisasi. Temperatur karbonisasi merupakan bagian yang penting dalam menghasilkan karbon karena jika temperaturnya terlalu rendah zat organik ataupun senyawa karbon tidak dapat terurai menjadi gas, jika temperaturnya terlalu tinggi akan mengakibatkan rusaknya karbon maka karbon yang terbentuk semakin sedikit 
sehingga menurunkan kualitas bahan bakar [16]. Karbonisasi dilakukan bertujuan untuk menurunkan kadar zat menguap sehingga dapat dihasilkan bahan bakar karbon memiliki mutu yang baik. Untuk mendapatkan hasil karbonisasi bermutu tinggi diperlukan perlakuan baik selama proses karbonisasi. Dalam upaya pemanfaatan biomassa sebagai sumber energi alternatif yang memiliki mutu tinggi sebagai sumber energi yang renewable, maka penelitian ini akan melakukan pembuatan briket arang berbahan baku serat buah pinang dengan perbedaan temperatur dan waktu karbonisasi.

Pemilihan perbandingan komposisi bahan penyusun briket didasarkan pada nilai kalornya yang tertinggi. Atas dasar tersebut maka komposisi yang paling efisien adalah komposisi bahan serat buah pinang $80 \%$ dan 20\% tepung tapioka yang diadopsi dari penelitian Purnama Anandi [13].

Tabel 2. Hasil pengujian nilai kalor briket serat buah pinang (Purnama Anandi, 2019).

\begin{tabular}{ccccccc}
\hline \multirow{2}{*}{ Komposisi } & \multicolumn{5}{c}{ Pengujian } & Rata-rata \\
\cline { 2 - 6 } & 1 & 2 & 3 & 4 & 5 & (KJ/Kg) \\
\hline $\begin{array}{c}90 \% \text { SP + } \\
\text { 10\% Tapioka }\end{array}$ & $9.715,78$ & $10.409,8$ & $10.062,8$ & $8.674,8$ & $10.756,8$ & $9.923,97$ \\
\hline $\begin{array}{c}80 \% \text { SP + } \\
\text { 20\% Tapioka }\end{array}$ & $11.450,7$ & $11.797,7$ & $12.838,7$ & $13.185,7$ & $12.491,7$ & $12.352,9$ \\
\hline $\begin{array}{c}70 \% S P+ \\
\text { 30\% Tapioka }\end{array}$ & $9.021,79$ & $10.756,8$ & $11.103,7$ & $11.797,7$ & $11.450,7$ & $10.826,2$ \\
\hline $\begin{array}{c}\text { 60\%SP + } \\
40 \% \text { Tapioka }\end{array}$ & $12.144,7$ & $11.797,7$ & $7.980,82$ & $11.450,7$ & $12.491,7$ & $11.034,3$ \\
\hline
\end{tabular}

Berdasarkan hasil pengujian nilai kalor serat buah pinang didapatkan harga nilai kalor tertinggi sebesar $12.352,9 \mathrm{KJ} / \mathrm{Kg}$. Nilai kalor ini masih jauh lebih rendah dibandingkan dari standar briket SNI. Rendahnya nilai kalor briket ini menunjukkan bahwa perlu dilakukan usaha dalam meningkatkan nilai kalor serat buah pinang melalui proses karbonisasi. Hal ini sejalan dengan penelitian yang dilakukan Erwin Junary dkk, [6] tentang pengaruh waktu dan temperatur karbonisasi dalam pembuatan briket arang. Berdasarkan penelitian Erwin Junary dkk, [6] dapat disimpulkan bahwa dengan melakukan proses karbonisasi dapat meningkatkan nilai kalor.

\section{METODE PENELITIAN}

Penelitian yang dilakukan merupakan penelitian eksperimen (experimental research) yang bertujuan untuk mengetahui besarnya pengaruh temperatur dan waktu karbonisasi terhadap nilai kalor briket arang serat buah pinang. Penelitian eksperimen adalah suatu metode penelitian yang digunakan dalam mencari pengaruh perlakuan tertentu terhadap yang lain dalam kondisi yang terkendalikan. Metode yang digunakan dalam pembuatan briket arang dengan membuat briket terlebih dahulu sebelum menjadi briket arang.

\section{Pembuatan Briket Serat Buah Pinang}

Bahan limbah serat buah pinang dikeringkan dengan cara penjemuran di bawah sinar matahari kemudian dilakukan tahap penggilingan. Partikel serat buah pinang hasil penggilingan kemudian diayak dengan ukuran saringan partikel 50 mesh. Pembuatan briket arang serat buah pinang menggunakan perekat tepung tapioka dengan perbandingan komposisi 80\% : 20\%. Perekat sebanyak 20\% dengan massa 8 gr dibutuhkan untuk pembuatan 1 buah briket, kemudian jumlah tersebut digunakan untuk pembuatan 5 sampel 
briket menjadi 40 gr dilarutkan dengan air sebanyak $250 \mathrm{ml}$ dan dipanaskan hingga menjadi gel pada saat temperatur $65^{\circ} \mathrm{C}$. Pencetakan briket dibuat berbentuk silinder berdiameter 50 $\mathrm{mm}$, tinggi $40 \mathrm{~mm}$ dan memiliki lubang tengah berdiameter $12 \mathrm{~mm}$ atau memiliki volume 74 $\mathrm{cm}^{3}$. Pengeringan briket setelah pencetakan menggunakan oven dengan suhu $120^{\circ} \mathrm{C}$ selama 4 jam. Briket setelah di oven selanjutnya dikarbonisasi menggunakan furnace chamber pada temperatur karbonisasi $200^{\circ} \mathrm{C}, 250^{\circ} \mathrm{C}, 300^{\circ} \mathrm{C}, 350^{\circ} \mathrm{C}$ dan $400^{\circ} \mathrm{C}$ dengan variasi waktu tahan 30, 60 dan 90 menit. Setiap kondisi spesimen dilakukan pengujian sebanyak 5 kali mengikuti jumlah sampel sehingga jumlah keseluruhan sampel uji yang digunakan adalah 75 sampel uji.

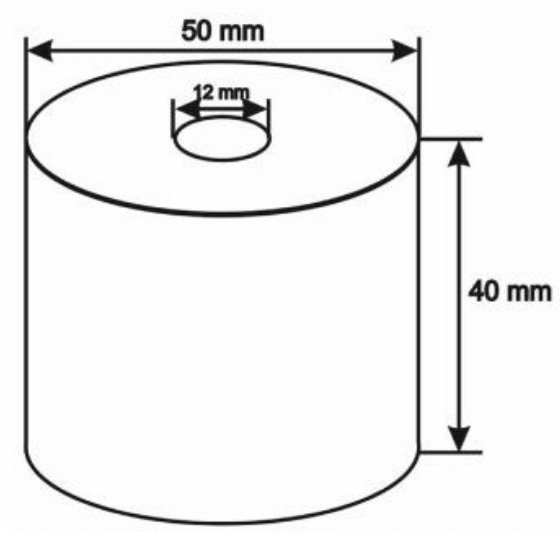

Gambar 1. Dimensi Pencetakan Briket Sabut Pinang

\section{Pengujian Briket Arang Serat Buah Pinang}

Sampel briket arang setelah proses karbonisasi di uji sebanyak 0,2 gr dan di campurkan dengan penambahan oksigen sebesar 10 atm untuk menguji nilai kalor menggunakan Bomb Calorimeter. Data yang didapatkan dari pengujian menggunakan alat ini berupa selisih suhu awal dan suhu akhir pembakaran briket arang serat buah pinang, kemudian dilakukan perhitungan nilai kalor menggunakan persamaan:

$$
\mathrm{Nbb}=\frac{(\mathrm{H} . \Delta \mathrm{T})}{\mathrm{mbb}} \mathrm{KJ} / \mathrm{Kg}
$$

\section{HASIL DAN PEMBAHASAN}

Studi peningkatan nilai kalor briket serat buah pinang yang dipilih pada proses karbonisasi adalah komposisi $80 \%$ sabut pinang dan 20\% tapioka. Komposisi ini menunjukkan nilai kalor tertinggi dari beberapa variasi dengan perekat tapioka.

\section{Hasil Proses Karbonisasi Briket Serat Buah Pinang}

Gambar 2 (a) adalah briket arang yang dikarbonisasi pada waktu tahan 30 menit. Briket ini diarangkan pada variasi suhu $200{ }^{\circ} \mathrm{C}, 250{ }^{\circ} \mathrm{C}, 300{ }^{\circ} \mathrm{C}, 350{ }^{\circ} \mathrm{C}$ dan $400{ }^{\circ} \mathrm{C}$, memiliki warna hitam yang signifikan hanya terlihat pada sampel yang diarangkan pada suhu $400{ }^{\circ} \mathrm{C}$. Gambar 2 (b) adalah briket yang dikarbonisasi pada waktu tahan 60 menit. Briket ini diarangkan pada variasi suhu $200{ }^{\circ} \mathrm{C}, 250{ }^{\circ} \mathrm{C}, 300{ }^{\circ} \mathrm{C}, 350{ }^{\circ} \mathrm{C}, 400{ }^{\circ} \mathrm{C}$, memiliki warna hitam yang signifikan mulai terlihat pada sampel yang diarangkan pada suhu $300{ }^{\circ} \mathrm{C}$. Gambar 2 (c) adalah briket yang dikarbonisasi pada waktu tahan 90 menit. Briket ini diarangkan pada variasi suhu 200 ${ }^{\circ} \mathrm{C}, 250{ }^{\circ} \mathrm{C}, 300{ }^{\circ} \mathrm{C}, 350{ }^{\circ} \mathrm{C}, 400{ }^{\circ} \mathrm{C}$, memiliki warna hitam mulai terlihat pada sampel yang diarangkan pada suhu $250{ }^{\circ} \mathrm{C}$. Setelah proses karbonisasi selesai, briket dikeluarkan dari furnace dan dibiarkan selama terjadinya penurunan suhu tidak membuka langsung bungkusan aluminium foil karena hal tersebut akan menyebabkan arang yang masih panas dapat beraksi dengan oksigen (02) sehingga dapat mengakibatkan zat-zat karbon dalam arang terbakar dan menyisakan banyak abu. 


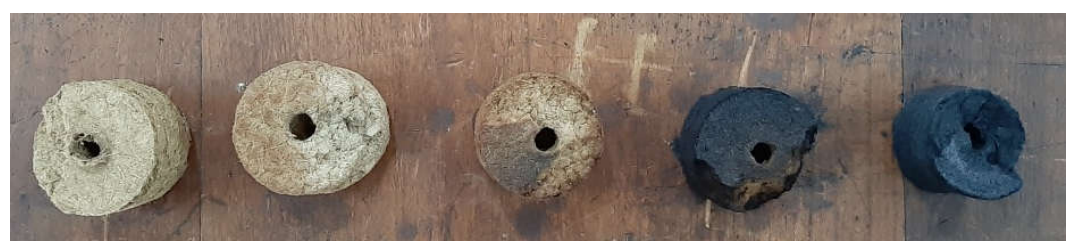

(a)

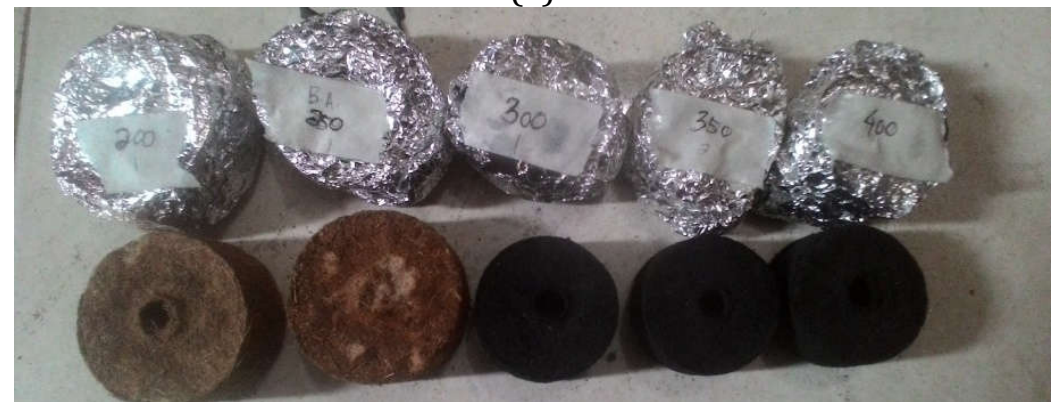

(b)

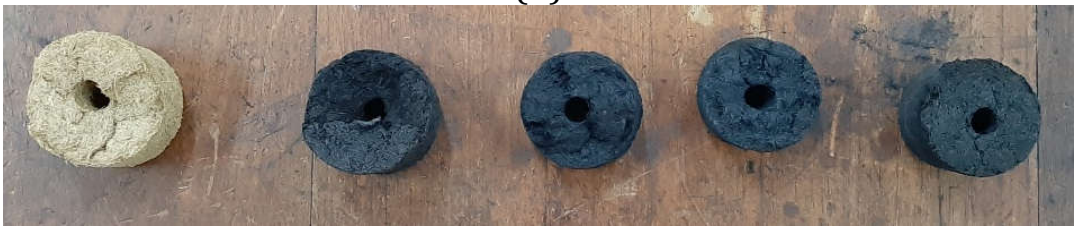

(c)

Gambar 2. Hasil proses Karbonisasi Briket Serat Buah Pinang

\section{Hasil Pengujian Nilai Kalor Briket Arang Serat Buah Pinang}

Proses pengujian dilakukan menggunakan sampel sebanyak 0,2 gr. Sampel dimasukkan kedalam tabung bomb calorimeter dan diberi campuran udara sebesar 10 atm. Proses pembakaran didalam tabung bomb dilakukan pada saat selama 1 menit setelah tombol start ditekan. Pengujian dilakukan sebanyak 5 kali pengulangan dari tiap kondisi spesimen. Hasil uji nilai kalor briket arang serat buah pinang ditunjukkan pada tabel 3.

\section{Tabel 3. Hasil uji Nilai Kalor Briket Arang Berbahan Baku Serat Buah Pinang}

\begin{tabular}{ccc}
\hline Suhu $\left({ }^{\circ} \mathrm{C}\right)$ & Waktu & $\begin{array}{c}\text { Nilai Kalor } \\
(\mathrm{KJ} / \mathrm{Kg})\end{array}$ \\
\hline \multirow{3}{*}{200} & 30 & 7821,19968 \\
\cline { 2 - 3 } & 60 & 10319,54208 \\
\cline { 2 - 3 } 250 & 90 & 10728,99264 \\
\cline { 2 - 3 } & 30 & 8994,03264 \\
\cline { 2 - 3 } & 60 & 12318,216 \\
\hline \multirow{3}{*}{300} & 90 & 12741,54624 \\
\hline \multirow{3}{*}{350} & 30 & 10597,13568 \\
\hline & 60 & 20979,13632 \\
\hline & 90 & 13220,3952 \\
\hline \multirow{2}{*}{400} & 30 & 11138,4432 \\
\hline & 60 & 18897,18432 \\
\hline & 90 & 8994,03264 \\
\hline & 30 & 12318,216 \\
\hline & 90 & 12741,54624 \\
\hline
\end{tabular}


Hasil Uji nilai kalor briket arang yang dibuat dari serat buah pinang menggunakan perekat tapioka pada komposisi $80 \%$ : 20\% dengan variasi waktu tahan ditunjukkan pada gambar 2 .

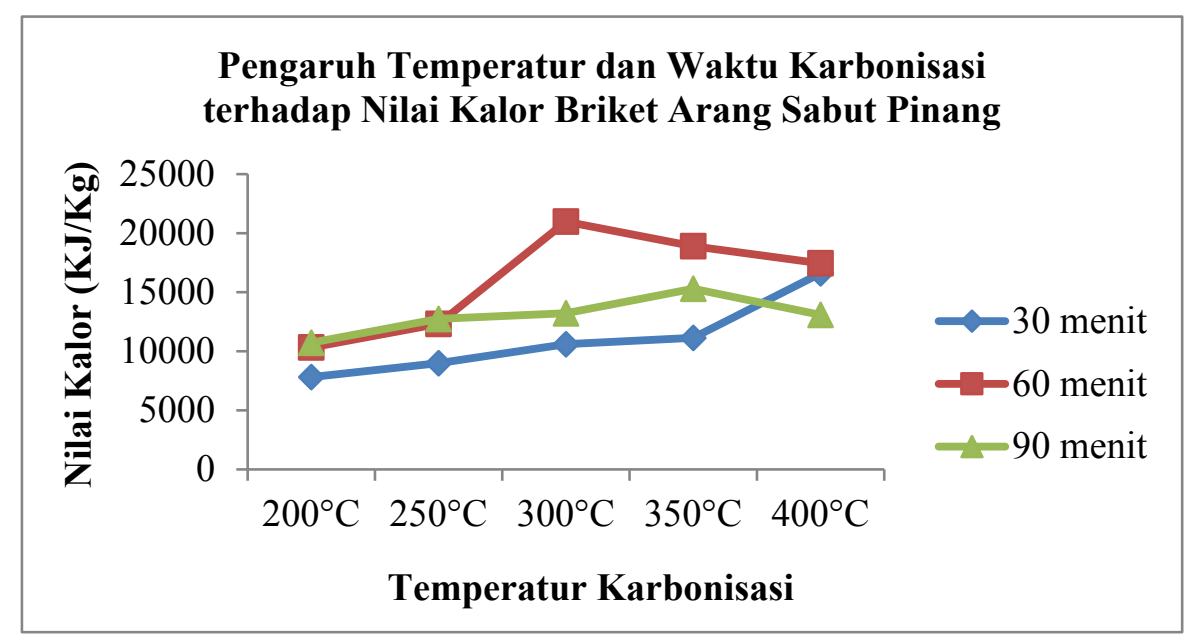

Gambar 3. Grafik Hasil pengujian nilai kalor briket arang serat buah pinang komposisi $80 \%$ sabut

\section{Pembahasan} pinang dan $20 \%$ tapioka

Gambar 3 menunjukkan bahwa meningkatnya temperatur karbonisasi dapat meningkatkan nilai kalor. Nilai kalor yang dicapai briket arang terlihat bervariasi pada waktu pembakaran yang sama dan terdapat perbedaan besarnya kenaikan suhu pembakaran pada masing-masing briket arang sabut pinang yang dipengaruhi oleh perbedaan temperatur dan waktu karbonisasi. Perlakuan waktu tahan pada proses karbonisasi memperlihatkan kondisi briket arang yang berbeda jauh. Briket yang dikarbonisasi pada waktu tahan selama 60 menit pada suhu $300^{\circ} \mathrm{C}$ terjadi kenaikan nilai kalor yang signifikan. Kenaikan nilai kalor disebabkan temperatur karbonisasi yang semakin meningkat yang mengakibatkan terurainya gas-gas seperti $\mathrm{CO}, \mathrm{CO}_{2}, \mathrm{CH}_{4}, \mathrm{H}_{2}$ dan senyawa hidrokarbon pada briket sehingga meningkatkan terbentuknya karbon. Terbentuknya karbon dipengaruhi oleh rendahnya kadar air. Kadar air rendah pada briket selama proses karbonisasi membantu proses penguapan air terjadi lebih cepat seiring dengan menguapnya senyawa hidrokarbon [6].

Kadar air akan semakin menurun seiring dengan bertambahnya suhu dan waktu karbonisasi [16]. Tingginya nilai kalor pada briket arang dapat dipengaruhi oleh besarnya kandungan karbon pada briket arang, hal tersebut sesuai teori bahwa semakin besarnya kadar karbon yang terbentuk dapat memperpanjang waktu nyala briket arang dan memiliki nilai kalor pembakaran yang tinggi [6]. Nilai kalor briket arang dapat dipengaruhi oleh ukuran partikel yang terbakar. Ukuran partikel yang semakin kecil akan meningkatkan suhu pembakaran semakin tinggi [18].

Nilai kalor tertinggi yang dicapai oleh briket arang terdapat pada waktu tahan selama 60 menit pada suhu $300^{\circ} \mathrm{C}$. Grafik pada suhu $350^{\circ} \mathrm{C}$ waktu 60 menit mengalami penurunan nilai kalor. Suhu karbonisasi yang semakin tinggi seharusnya dapat mengalami kenaikan nilai kalor. Hasil penelitian ini dapat disebabkan oleh sedikitnya bahan bakar yang terbakar pada saat pengujian yang diakibatkan oleh tekanan udara pada saat pengisian udara dalam pencampuran bahan bakar pada tabung bomb kalorimeter. Perlakuan pada suhu karbonisasi yang sama, yaitu $400^{\circ} \mathrm{C}$ pada waktu tahan 30 menit menunjukkan perbedaan yang nyata pada waktu tahan 60 menit dan 90 menit. Hal ini disebabkan pengarangan pada temperatur yang tinggi dalam waktu yang lama akan merusak zat karbon yang terbentuk menjadi terbakar sehingga memperbanyak kadar abu dan menurunkan mutu briket. Bertambahnya suhu dan lamanya waktu karbonisasi mengakibatkan karbon bereaksi dengan unsur $\mathrm{O}_{2}$ yang 
terkandung dalam bahan bakar, akibatnya zat karbon terbakar menjadi $\mathrm{CO}_{2}$ dan $\mathrm{H}_{2}$ sehingga briket yang dihasilkan mengandung banyak abu. Hasil penelitian ini sesuai dengan teori bahwa semakin meningkat suhu dan waktu karbonisasi akan menurunkan kualitas briket arang yang mengandung banyak abu [6].

\section{SIMPULAN DAN SARAN}

\section{Simpulan}

Proses karbonisasi pada biomassa dapat memicu terbentuknya zat karbon, hal ini disebabkan oleh terurainya komponen selulosa dan lignin akibat temperatur tinggi selama karbonisasi dalam waktu tahan yang lama, dimana sebagian besar terbuang menjadi gas hidrokarbon, $\mathrm{CO}_{2}$ dan uap air. Hasil penelitian menunjukkan nilai kalor optimal terdapat pada temperatur karbonisasi $300^{\circ} \mathrm{C}$ dengan waktu tahan 60 menit sebesar 20.979,13632 $\mathrm{KJ} / \mathrm{Kg}$. Temperatur karbonisasi yang terlalu tinggi dapat merusak karbon yang terbentuk dalam briket arang, akibatnya karbon bereaksi dengan unsur $\mathrm{O}_{2}$ pada bahan baku sehingga menyebabkan karbon terbakar sehingga dapat menyisakan banyak abu.

\section{Saran}

Studi lanjutan yang dapat diambil dalam meningkatkan kualitas briket arang adalah dengan cara mencampurkan komposisi bahan penyusunnya dengan biomassa lain sebagai briket yang memiliki kualitas tinggi. Briket arang serat buah pinang dapat dikembangkan sebagai salah satu produk olahan biomassa yang dapat bermanfaat sebagai sumber energi alternatif dalam mengurangi penggunaan bahan bakar fosil.

\section{DAFTAR RUJUKAN}

[1] Aprian Ramadhan P and Munawar Ali, "Pengolahan Sampah Plastik Menjadi Minyak Menggunakan Proses Pirolisis,” Jurnal, vol. 4, no. 1, pp. 44-53, 2010.

[2] Arni., Hosiana M.D.L., Anis Nismayanti, "Studi Uji Karakteristik Fisis Briket Bioarang Sebagai Sumber Energi Alternatif," Journal of Natural Science, vol. 3, no. 1, pp. 89-98, 2014.

[3] Arnida Mustafa, "Analisis Proses Pembuatan Pati Ubi Kayu (Tapioka) Berbasis Neraca Massa," AGROINTEK, vol.9, no. 2, pp. 127-133, 2015.

[4] ASTM D 2015, Standart Test Methlod for Gross Calorific Value of Coal and Coke by the Adiabatic Bomb Calorimeter. 2000.

[5] Erwin Junary., J. Prasetya.P., N. Herlina, "Pengaruh Suhu dan Waktu Karbonisasi terhadap Nilai Kalor dan Karakteristik pada Pembuatan Bioarang Berbahan Baku Pelepah Aren (Arenga Pinata)," Jurnal Teknik Kimia USU, vol. 4, no. 2, pp. 46-52, 2015

[6] Gustan Pari, "Pengaruh Selulosa terhadap Struktur Karbon Arang Bagian 1: Pengaruh Suhu Karbonisasi," Jurnal Penelitian Hasil Hutan, vol.29, no.1, pp. 33-45, 2011.

[7] Hendri Nurdin., Hasanuddin., D. Darmawi, "Karakteristik Nilai Kalor Tebu Tibarau sebagai Bahan Bakar Alternatif," Jurnal Inovasi Vokasional dan Teknologi, vol. 18, no. 1, pp. 19-24, 2018.

[8] Lina Lestari., Erzam S. Hasan., La. A \& Viska I.V, “Optimasi Ukuran Partikel, Komposisi Bahan dan Tekanan dalam Pembuatan Briket Arang Batang Sagu," Jurnal Aplikasi Fisika, vol. 10, no. 1, pp. 27-30, 2014.

[9] M. Masudul Hassan., Manfred H. Wagner, H.U. Zaman., Mubarak A. Khan., "PhysicoMechanical Performance of Hybrid Betel Nut (Areca catechu) Short Fiber/Seaweed Polypropylene Composite," Journal of Natural Fiber, vol. 7, no. 3, pp. 165-177, 2010.

[10] Mody Lempang, "Sifat-sifat Arang Aktif Tempurung Kemiri dan Aplikasinya sebagai Komponen Media Tumbuh pada Tanaman Melina," Institut Pertanian Bogor, Bogor, 2009. 
[11] Nodali Ndraha, "Uji Komposisi Bahan Pembuat Briket Bioarang Tempurung Kelapa dan Serbuk Kayu Terhadap Mutu yang Dihasilkan," Universitas Sumatra Utara, Medan, 2010.

[12] Purnama Anandi S.P, "Analisis Nilai Kalor Briket Serat Pinang sebagai Bahan Bakar Alternatif," Journal of Multidisciplinary Research and Development, vol. 1, no. 3, pp. 449452, 2019.

[13] Rosta Natalia S., Rosdaneli Hasibuan, "Pembuatan Briket dari Kulit Kakao menggunakan Perekat Kulit Ubi Kayu," Jurnal Teknik Kimia USU, vol. 6, no. 3, pp. 2017.

[14] Samsul Bahri, "Pemanfaatan Limbah Industri Pengolahan Kayu Untuk Pembuatan Briket Arang dalam Mengurangi Pencemaran Lingkungan di Nangroe Aceh Darussalam," USU, Medan, 2007.

[15] Satriyani Siahaan, M. Hutapea dan R. Hasibuan, "Penentuan Kondisi Optimum Suhu dan Waktu Karbonisasi pada Pembuatan Arang dari Sekam Padi, " Jurnal Teknik Kimia USU, vol. 2, no. 1, pp. 26-30, 2013.

[16] Suharsimi Arikunto, Prosedur Penelitian. Jakarta: P.T. Rineka Cipta, 2010.

[17] Willyanto A., Fandi. D. Suprianto., Sutrisno \& Andreas W. Kasrun, "Investigation on Biomass Briquette as Energy Source from Waste Leaf Cerbera Manghas, " JIRAE, vol. 1, no. 1, pp. 11-14, 2016.

[18] Yudha Setiadi, "Pengaruh Penggunaan Perekat Tapioka dan Damar terhadap Nilai Kalor Bahan Bakar Biobriket Tebu Tibarau," UNP, Padang, 2018

[19] Yuli Ristianingsih., Ayuning Ulfa \& Rachmi Syafitri K.S., "Pengaruh Suhu dan Konsentrasi Perekat terhadap Karakteristik Briket Bioarang Berbahan Baku Tandan Kosong Kelapa Sawit dengan Proses Pirolisis," Konversi, vol. 4 no. 2, pp. 16-22, 2015.

[20] https://sumbar.bps.go.id/dynamictable/2016/11/17/43/produksi-pinangperkebunan-rakyat-2008-2016.html 